Kare, M. R. (1962). Quoted in f. small Anim. Pract. (1963), 4, 233.

Kare, M. R. \& Ficken, M. S. (I963). In Olfaction and Taste. Vol. I, p. 285 [Y. Zotterman, editor]. London: Pergamon Press.

Liljestrand, G. \& Zotterman, Y. (1954). Acta physiol. scand. 32, 29I.

Moulton, D. G., Ashton, E. H. \& Eayrs, J. T. (1960). Anim. Behav. 8, 117.

Neuhaus, W. (1953). Quoted by Moulton, D. G., Ashton, E. H. \& Eayrs, J. T. (1960).

Niccolini, P. (I954). Quoted by Moulton, D. G., Ashton, E. H. \& Eayrs, J. T. (1960).

Pfaffmann, C. (1941). F. cell. comp. Physiol. r7, 243.

Pfaffmann, C. (1965). Am. Psychol. 20, 2 I.

Wade, G. N. \& Zucker, I. (1969). Physiol. Behav. 4, 935.

Waterhouse, H. N. \& Fritsch, C. W. (1967). Lab. Anim. Care r7, 93.

Zotterman, Y. (1935). Skand. Arch. Physiol. 72, 73.

Zotterman, Y. (1956). Acta physiol. scand. 37,60.

\title{
Do laboratory animals like eating?
}

\section{By W. Lane-Petter, Houghton, Huntingdon}

Hunger and thirst are active, innate drives leading an animal to want to eat and drink. Satiety is said to be reached when the animal stops eating and drinking, even though more food and drink are still available. But, as Katz (1958) has pointed out, an animal that appears to have reached satiety may nevertheless resume eating if the same food is presented anew, or a different food is offered, or other animals are introduced, or for other reasons. This suggests that the innate hunger drive is modified by the nature of the food, its method of presentation and the social circumstances accompanying feeding.

There are obvious parallels in the field of human gluttony, from the Lord Mayor's banquet to the private dinner party, which encourage ritual overeating. But, although these parallels are apparent, it cannot be therefore inferred that animals have food preferences. What evidence exists is far from conclusive and the greater part of it is observational or anecdotal.

\section{Limitation of choice}

Laboratory animals are dependent for all their dietary needs on what is offered to them in the cage. They have to eat this or starve. Since in most instances the food offered is in the form of a compressed compound pellet, there is no scope for exercising a food preference. It has been pointed out that a compound pellet designated by a name or number to identify it with a formula of ingredients may give no more than the appearance of constancy (Porter, Lane-Petter \& Horne, 1963). Moreover, even the best of the compound diets in use may be less than nutritionally optimal in all circumstances. Most of such diets are unpalatable by human standards; neither the taste nor the mealy consistency is pleasant. And the habit of many mice and some rats, as well as guinea-pigs, rabbits and many other laboratory species, of wasting their food suggests that they too often find it unpalatable. However, they 29 (2) II 
may become habituated to it and then they will be reluctant to change to a different diet. Scott \& Scott (1967) have described how dogs and cats can become so attached to a familiar diet that they will starve rather than accept a change.

Some animals are highly specialized feeders. The koala eats little or nothing but eucalyptus leaves, and the giant panda has to have a regular supply of bamboo. Colobus monkeys are leaf eaters in their natural state, but in zoos they can be persuaded to eat fruit and other suitable foods, and they appear to thrive on them. Many animals are mainly herbivorous or carnivorous, though seldom exclusively so, and others, including man, are omnivorous. Rats and mice are completely omnivorous; guinea-pigs and rabbits are fairly general herbivores, cats and dogs are general carnivores. These more or less catholic tastes contribute much to making these species and a few others related to them the common laboratory animals.

\section{Experimental and traditional feeders}

The omnivorous rat will try to eat anything that is edible, and often much that is not. In the laboratory, a plastic cage or water-bottle, or even aluminium or zinc, will be gnawed or chewed whenever suitably presented. Wild rats will attempt to chew through anything they come across, including lead-pipes. But the rat, faced with unfamiliar food, will only eat a small quantity, even though it may be hungry. If there follows no ill effect, it will return and eat a little more, until it has learned that the food is indeed good to eat, then it will eat its fill. This is the basis of prebaiting in rodent control: to put poison in the first, unfamiliar bait will only result in little or no bait being taken.

Thus, the rat is, more than most other mammals, an experimental feeder, using itself as its own experimental animal. It follows that the rat can be accustomed to accept food in almost any form, and that its acceptance is objective rather than a matter of taste or preference. Indeed, this is not unexpected, if it is remembered that the laboratory rat derives from the wild brown or sewer rat, which lives and thrives on urban effluents, and this more or less precludes its being a fastidious feeder.

To a somewhat less extent mice are also experimental feeders. So too are the young of many species of mammal, including puppies and young children, whose adults show much less enterprise.

In contrast there are the traditional feeders, not so limited in their acceptance of food as koalas or giant pandas, but by no means adventurous like the rat. Guineapigs, whose wild ancestors lived in areas of simple vegetation, some forms of which were edible while others were not, would have been at a disadvantage if every animal had, rat-like, to conduct the same feeding experiments on itself. It was more efficient biologically for the older animals to demonstrate what was good to eat, so that the young could eat this and nothing else. And, indeed, that is how the guinea-pig behaves in the laboratory. The young have to be shown what to eat by their elders, and the elders are unwilling to attempt to eat anything that they have not been taught to recognize as food. I have seen guinea-pigs that became scorbutic, even 
though offered fresh savoy cabbage every day: they had never been shown that this was good to eat.

An example of introducing a new tradition of feeding is seen in a film of a Japanese monkey colony, maintained on an island off the coast of Japan. The monkeys were offered sweet-potatoes, as dug, with some adherent soil. Juvenile monkeys learned experimentally to rinse the sweet-potatoes in sea-water, to remove the soil, and after a while the adults adopted the same habit, which thereafter became traditional in this colony (D. Miyadi, 1954, personal communication).

\section{Perversion of appetite and palatability}

Sugar is very attractive to rats and mice, as to many other animals. Valenstein, Kakolewski \& Cox (I967) reported on the preference of rats for sweet drinkingwater, and noted that if the sweetener was saccharin much more was drunk than if it was glucose. There are centres in the hypothalamus for hunger and for satiety, and it appears that satiety is reached when a certain number of calories have been ingested, and only then is the desire for sweet drink extinguished.

Katz (I958) gives many examples of altered feeding preferences in animals that are malnourished. A calcium-deficient mammal or bird will be more likely to eat bones, bone-meal, egg-shells or other calcareous substances than a normal animal. If the calcium is given in such a way that the animal has no opportunity of tasting it, the perverted appetite will nevertheless become corrected when the calcium level in the body is restored.

It is thus not the satisfaction of a subjective desire for the missing constituent, but a metabolic unbalance that perverts the appetite.

Cannibalism is another perversion of appetite that may be provoked by malnutrition, for example, protein deficiency or an imbalance between thiamine and manganese; but it may also be caused by a number of other environmental influences (Lane-Petter, I968).

Tribe \& Gordon (I953) fed rats on diets which differed in the kind of starch they contained, the least palatable being unground potato starch. Some of the diets were also deficient in vitamin $B$ complex. The rats showed an ability to choose a vitamin-fortified diet in preference to a deficient diet, but in other respects they did not always select the better of two diets offered. Their choice seemed to be guided more by the effect of eating than by gustation.

Porter ( 1963 ) has discussed palatability of food for rats and mice, and concludes that there is no strong relationship between palatability and nutritive value.

When a seriously salt- and water-depleted man is offered water containing salt, the salt tends to taste sweet, and only when the electrolyte balance has been restored does it taste saline. However, since one is here dealing with primary taste sensations, too much cannot be extended into the realm of food preference, in which flavours other than primary taste are involved. In the same way, human taste preferences cannot safely be ascribed to animals, all the more because they are so often socially or traditionally ordered. 


\section{Feeding habits of rats and mice}

Like most laboratory animals, rats and mice are intermittent feeders, with their peak feeding time between about 18.00 and 24.00 hours. If given the choice, they will show a predilection for moist mash over dry feeds, for sweet over non-sweet, and for baked biscuit over compressed pellets.

If offered pellets in a wire basket, both species will attempt to pull them through the wire into the cage; rats will then pick up the pellets and eat them, but mice will often reject the food and pull more through.

Both species, but rats more than mice, will manoeuvre pellets by means of their noses through the wire in such a way as to toss individual pellets out of the cage on to the shelf or floor; it is uncertain whether this is a mark of disapproval of the diet, or just plain mischief. Rats, especially, will play with food pellets, rolling them around inside the cage, if their appetite is satisfied.

A male rat on its own is a poor feeder. Uncomfortable cages, wet or dirty bedding, noise and other disturbances, and an unfavourable social environment will all reduce appetite. Lactating rats may eat their body-weight in dry feed in $3 \mathrm{~d}$, mice in $2 \mathrm{~d}$. This is not only a remarkable achievement for the appetite centre, but makes exceptional demands on the digestion.

\section{Conclusion}

Hediger (rg66) emphasizes the different dietary needs of zoo animals on the one hand, and domestic and laboratory animals on the other. He quite rightly points out that, for a zoo animal, food is more than nutritional replenishment: dealing with food is an activity that contributes to the realization of normal behaviour. Much the same is true, if in a lower key, of laboratory animals. In them, the acceptability of a diet is not to be judged solely by gustatory or nutritional standards, for food is a part of the day's total experience.

There is not enough evidence to say whether laboratory animals can exercise a food preference in the subjective sense: whether, in a word, they like eating. But they do manifest the phenomena of hunger and satiety, both of which may be influenced by factors other than metabolic repletion; of differential choice of food ingredients; of perversion of appetite in malnutrition; of a wide variety of feeding practices, both experimental and traditional; and of treating food substances as play objects. The ideal feeding of laboratory animals should take all these factors into account.

\section{REFERENCES}

Hediger, H. (1 966). Int. Zoo Yb. 6, 37 .

Katz, D. (I958). In Animals and Men. p. I16. London: Pelican Books.

Lane-Petter, W. (1968). Proc, R, Soc. Med. 61, 1295.

Porter, G. (I963). In Animals for Research p. 32 [W. Lane-Petter, editor]. London: Academic Press.

Porter, G., Lane-Petter, W. \& Horne, N. (1963). Z. Versuchstierk. 2, 75, I7 I.

Scott, P. P. \& Scott, M. G. (1967). In Husbandry of Laboratory Animals p. 164 [M. L. Conalty, editor]. London: Academic Press.

Tribe, D. E. \& Gordon, J. G. (1953). Br. F. Nutr. 7, 202.

Valenstein, E. S., Kakolewski, J. W. \& Cox, V. C. (1967). Science, N.Y. 156, 942. 